\title{
Mechanisms of relaxation induced by flavonoid ayanin in isolated aorta rings from Wistar rats
}

\author{
Rosalía Carrón, QF, DSc, ${ }^{1}$, Eva Sanz, QF, MSc ${ }^{2}$, Pilar Puebla, QF, DSc ${ }^{1}$, \\ María Luisa Martín, QF, DSc ${ }^{1}$, LuIs San Román, QF, DSc ${ }^{3}$, \\ Mario Francisco Guerrero, MD, DSc ${ }^{4}$
}

\section{SUMMARY}

Introduction: This study shows the relaxant effect induced by ayanin in aorta rings from Wistar rats linked to nitric oxide/ cyclic-GMP pathway. This flavonoid is the prevalent compound obtained from Croton schiedeanus Schlecht (Euphorbiaceae), specie used in Colombian folk medicine for the treatment of arterial hypertension.

Objectives: To identify possible action mechanisms of vascular relaxation induced by ayanin (quercetin 3,4',7-trimethyl ether).

Methodology: Isolated aorta rings from Wistar rats obtained at the Animal House of the University of Salamanca were contracted with $\mathrm{KCl}(80 \mathrm{mM})$ or phenylephrine $\left(\mathrm{PE}, 10^{-6} \mathrm{M}\right)$ and exposed to ayanin $\left(10^{-6}-10^{-4} \mathrm{M}\right)$. Then, the effect of ayanin was assessed in deendothelized rings contracted with $\mathrm{PE}$ and in intact rings contracted with PE previously incubated with: ODQ $\left(10^{-6} \mathrm{M}\right)$, L-NAME $\left(10^{-4} \mathrm{M}\right)$, L-NAME plus D- and L-arginine $\left(10^{-4} \mathrm{M}\right)$, indomethacin $\left(5 \times 10^{-6} \mathrm{M}\right)$, dipyridamole $\left(3 \times 10^{-7} \mathrm{M}\right)$, glibenclamide $\left(10^{-6} \mathrm{M}\right)$, propranolol $\left(10^{-6} \mathrm{M}\right)$, verapamil $\left(10^{-7} \mathrm{M}\right)$ or atropine $\left(3 \times 10^{-5} \mathrm{M}\right)$. In addition, the relaxant effect of acetylcholine (Ach, $10^{-8}-3 \times 10^{-4} \mathrm{M}$ ), and sodium nitroprusside ( $\mathrm{SNP}, 10^{-9}-3 \times 10^{-5} \mathrm{M}$ ) was assessed in the presence and absence of ayanin $\left(10^{-6} \mathrm{M}\right)$.

Results: Ayanin induced a greater concentration-dependent relaxation in vessels contracted with phenylephrine $\left(\mathrm{pEC}_{50}\right.$ : $5.84 \pm 0.05$ ), an effect significantly reduced by deendothelization and by both ODQ and L-NAME. L-arginine was able to reverse the effect of L-NAME. Indomethacin weakly inhibited ayanin response. Dipyridamole, glibenclamide, propranolol, verapamil, and atropine did not affect ayanin relaxation. Ayanin did not have any effect on the relaxation elicited by acetylcholine (ACh), while weakly decreasing the relaxation induced by sodium nitroprusside (SNP).

Conclusion: Ayanin induces endothelium-dependent relaxation in the rat aorta mainly related to nitric oxide/cGMP pathway, according to the response observed in the presence of L-NAME, L-arginine and ODQ.

Keywords: Ayanin; Croton; Endothelium-dependent relaxing factors; Flavonoids; Aorta.

\section{Mecanismos de relajación inducidos por el flavonoide ayanina en la aorta de ratas Wistar}

\section{RESUMEN}

Introdución: Este estudio muestra el efecto vasodilatador inducido por ayanina en anillos de aorta de ratas Wistar vinculado con la vía óxido nítrico/GMP-cíclico. Este flavonoide es el compuesto mayoritario aislado de Croton schiedeanus Schlecht (Euphorbiaceae), especie utilizada en la medicina popular colombiana para el tratamiento de la hipertensión arterial.

Objetivos: Identificar los posibles mecanismos vasodilatadores inducidos por la ayanina (quercetin 3,4',7-trimetileter).

Metodología: Se adicionó ayanina $\left(10^{-6}-10^{-4} \mathrm{M}\right)$ a anillos aislados de aorta procedentes de ratas Wistar contraídos con $\mathrm{KCl}(80 \mathrm{mM})$ o fenilefrina $\left(10^{-6} \mathrm{M}\right)$. Luego se evaluó el efecto de la ayanina en anillos sin endotelio contraídos con fenilefrina y en anillos íntegros, contraídos con fenilefrina, previamente incubados con: ODQ $\left(10^{-6} \mathrm{M}\right)$, L-NAME $\left(10^{-4} \mathrm{M}\right)$, L-NAME más

1. Professor, Laboratorio de Farmacognosia y Farmacología, Departamento de Fisiología y Farmacología, Facultad de Farmacia, Universidad de Salamanca, Salamanca, Spain. e-mail: rcarron@usal.es puebla@usal.es marisam@usal.es

2. Pharmacy Resident, Departamento de Química Farmacéutica, Facultad de Farmacia, Universidad de Salamanca, Salamanca, Spain. e-mail: esliebana@hotmail.com

3. Full Professor, Universidad de Salamanca, Salamanca, Spain. e-mail: 1sanro@usal.es

4. Associate Professor, Departamento de Farmacia, Facultad de Ciencias, Universidad Nacional de Colombia, Bogotá, Colombia. e-mail: mfguerrerop@unal.edu.co

Received for publication July 6, 2009 Accepted for publication January 12th, 2010 
L- o D-arginina $\left(10^{-4} \mathrm{M}\right)$, indometacina $\left(5 \times 10^{-6} \mathrm{M}\right)$, dipiridamol $\left(3 \times 10^{-7} \mathrm{M}\right)$, glibenclamida $\left(10^{-6} \mathrm{M}\right)$, propranolol $\left(10^{-6} \mathrm{M}\right)$, verapamilo $\left(10^{-7} \mathrm{M}\right)$ o atropina $\left(3 \times 10^{-5} \mathrm{M}\right)$. Además se examinó la relajación inducida por acetilcolina (Ach, $\left.10^{-8}-3 \times 10^{-4} \mathrm{M}\right)$ y nitroprusiato de sodio (SNP, $\left.10^{-9}-3 \times 10^{-5} \mathrm{M}\right)$ en presencia y ausencia de ayanina $\left(10^{-6} \mathrm{M}\right)$.

Resultados: La ayanina produjo una mayor relajación en los anillos contraídos con fenilefrina $\left(\mathrm{pEC}_{50}: 5.84 \pm 0.05\right.$ ), efecto que se redujo en anillos sin endotelio o en anillos íntegros preincubados con ODQ y L-NAME. L-arginina fue capaz de revertir la respuesta inducida por L-NAME. La indometacina inhibió discretamente la relajación generada por la ayanina. El dipyridamol, la glibenclamida, el propranolol, el verapamilo y la atropina no modificaron el efecto de la ayanina. La ayanina no afectó la relajación inducida por la acetilcolina y débilmente disminuyó la inducida por el nitroprusiato de sodio.

Conclusión: La ayanina induce una relajación dependiente del endotelio en la aorta de rata, efecto vinculado principalmente con la vía de óxido nítrico/GMP cíclico, de acuerdo con la respuesta observada en presencia de LNAME, ODQ y L-arginina.

Palabras clave: Ayanina; Croton; Factores relajantes endotelio-dependientes; Flavonoides; Aorta.

Polyphenolic compounds have extensively demonstrated beneficial cardiovascular effects in humans ${ }^{1-4}$. Among them, flavonoids constitute a large group of phenolic phytochemicals, which have been widely described in the literature as vasodilator compounds $^{5-9}$. Most flavonoids described to date exhibit a relaxant effect independent of the presence of a functional endothelium ${ }^{6,9,10}$, however, endotheliumdependent vasorelaxant effects have also been reported for some of these compounds ${ }^{8,11-13}$.

Screening tests of medicinal plants used by Colombian folk tradition as antihypertensives, found that ethanolic and aqueous extracts of Croton schiedeanus Schlecht (Euphorbiaceae) were able to decrease blood pressure in spontaneously hypertensiverats and toelicitsignificant vasorelaxant effects in isolated aorta rings ${ }^{14}$. Consequently abio-guided phytochemical fractionating was performed to identify their active principles, and ayanin (quercetin 3,4',7-trimethyl ether) (Figure 1) was isolated as one of them ${ }^{15}$.

The relaxant properties of ayanin on smooth muscle have been demonstrated in isolated tracheal rings ${ }^{16}$, but until now, its potential profile as a vasorelaxant agent is not sufficiently known. Therefore, the aim of this work<smiles>COc1cc(O)c2c(=O)c(OC)c(-c3ccc(OC)c(O)c3)oc2c1</smiles>

Figure 1. Chemical structure of ayanin (quercetin 3,4',7-trimethyl ether)

was to investigate whether ayanin relaxant mechanisms are due to interactions with one of the following key vascular factors: endothelium, NO/cyclic GMP pathway, prostanoid, $\mathrm{K}^{+}{ }_{\text {ATP }}$ channels, L-type calcium channels, ??receptors or muscarinic receptors.

\section{MATERIALS AND METHODS}

Extraction and isolation of ayanin. Ayanin (quercetin 3,4',7-trimethyl ether) (Figure 1) was isolated from C. schiedeanus Schlecht (Euphorbiaceae), a plant collected from the region of Tocaima, Cundinamarca, Colombia in November 1998 (voucher $n^{\circ}$ 432164). The aerial part of this specie was exhaustively extracted with $96 \%$ EtOH at room temperature. The combined extracts were concentrated under reduced pressure and partitioned to yield an aqueous extract and $\mathrm{CHCl}_{3}$. The residue of the $\mathrm{CHCl}_{3}$ extract was fractionated with $4 \% \mathrm{NaOH}$. Then ayanin was isolated from the neutral part by flash chromatography over silica gel with hexane-EtOAc (1:1). Ayanin was identified by comparing m-p., ${ }^{1} \mathrm{H}-$ NMR, ${ }^{13}$ C-NMR values with that reported ${ }^{17,18}$.

Rat aorta ring preparation. The experiments were conducted at the Pharmacology Laboratory in the School of Pharmacy at the University of Salamanca. Male Wistar rats (320-400 g) from the Animal House (PAESA001) were anaesthetized with ether and beheaded. The descending thoracic aorta was dissected and placed in an oxygenated Krebs solution with the following composition (in $\mathrm{mM}$ ): $\mathrm{NaCl}, 118.0 ; \mathrm{KCl}, 4.75 ; \mathrm{CaCl}_{2}$, 1.8; $\mathrm{MgSO}_{4}, 1.2 ; \mathrm{KH}_{2} \mathrm{PO}_{4}, 1.2 ; \mathrm{NaHCO}_{3}, 25 ;$ glucose, 11 and ascorbic acid 0.1 . 
Rings of thoracic aorta (4-6 mm long) were carefully excised and submerged in tissue bath chambers containing $5 \mathrm{ml}$ of Krebs solution of bathing medium maintained at $37^{\circ} \mathrm{C}$ and bubbled with $95 \% \mathrm{O}_{2}$ and $5 \%$ $\mathrm{CO}_{2}$ gas mixture $(\mathrm{pH}=7.4)$. Rings were mounted by means of two parallel L-shaped stainless-steel holders inserted into the lumen. One holder served as an anchor, while the other was connected to a force-displacement transducer (Harvard UF1) to measure isometric contractile force recorded by a MacLab/8-computer system (AD InstruMents Ltd, London, UK). The rings were stretched progressively to an optimal basal tension of $2 \mathrm{~g}$, determined by length-tension relationship experiments and, then, allowed to equilibrate for $60 \mathrm{~min}$., and changing the bath fluid every 15-20 min. When necessary, the endothelium was removed by rubbing the intimal surface with a wooden stick. The presence of functional endothelium was assessed by the ability of ACh $\left(10^{-6} \mathrm{M}\right)$ to induce more than $50 \%$ relaxation of rings pre-contracted with phenylephrine $\left(\mathrm{PE}, 10^{-6} \mathrm{M}\right)^{19}$. Each preparation was allowed to equilibrate for at least $60 \mathrm{~min}$. prior to initiation of experimental procedures and during this period, the incubation media were changed every $20 \mathrm{~min}$. before the addition of drugs.

Ethical issues. In all of these experiments, the provisions regarding the protection of animals used for experimental purposes in current Spanish legislation (Real Decreto 1201/2005), European Community (EEC $86 / 609$ ) and specifications were adhered to.

Experimental procedures. To observe if ayanin induces relaxant effects, intact aorta rings incubated in Krebs solution were stimulated with PE $\left(10^{-6} \mathrm{M}\right)$ or high $\mathrm{KCl}(80 \mathrm{mM})$ until the contractile response reached a steady tension. Then ayanin was added in progressively cumulative concentrations $\left(10^{-7}-10^{-4} \mathrm{M}\right)$ at $30 \mathrm{~min}$. intervals.

To study possible mechanisms related to the relaxant effects induced by ayanin, the following protocols were performed: First, the roll of endothelium was studied adding the flavonoid in similar way in deendothelized PE contracted rings. To assess whether nitric oxide, cGMP, phosphodiesterase- $5, \mathrm{~K}^{+}{ }_{\text {ATP }}$ channels, prostanoid, betareceptor, L-type calcium channels, or muscarinic receptors are related to the relaxant mechanisms induced by ayanin, this flavonoid was added to rings contracted with PE treated $30 \mathrm{~min}$. previously with one of the following substances, respectively: L-NAME $\left(10^{-4} \mathrm{M}\right.$
[Nw-nitro-L-arginine methyl ester hydrochloride]), a NO synthase inhibitor; ODQ $\left(10^{-6} \mathrm{M}[1 \mathrm{H}-[1,2,4]\right.$ oxadiazolo[4,3-a]quinoxalin-1-one]), a guanylate cyclase inhibitor; dipyridamole $\left(3 \times 10^{-7} \mathrm{M}\right)$, a cGMPphosphodiesterase 5 inhibitor; glibenclamide $\left(10^{-6} \mathrm{M}\right)$, a $\mathrm{K}^{+}{ }_{\text {ATP }}$ channel blocker; indomethacin $\left(5 \times 10^{-6} \mathrm{M}\right)$, a cyclooxygenase (COX) inhibitor; propranolol $\left(10^{-6} \mathrm{M}\right)$, a ?-adrenoceptor blocking agent; verapamil $\left(10^{-7} \mathrm{M}\right)$, a L-type calcium channels blocker and atropine $\left(3 \times 10^{-5}\right.$ $\mathrm{M})$, a muscarinic receptor blocking agent.

To advance in possible interactions with NO/cGMP pathway the inactive a-amino acid $\mathrm{D}$-arginine or the active L-arginine $\left(10^{-4} \mathrm{M}\right.$, substrate for NO synthesis) were added (10 $\mathrm{min}$. before) to rings incubated with $\mathrm{L}$ NAME $\left(10^{-4} \mathrm{M}\right)$. In addition, ayanin $\left(10^{-6} \mathrm{M}\right)$ was added (30 min. before) to rings contracted with PE $\left(10^{-6} \mathrm{M}\right)$ exposed to Ach $\left(10^{-8}-3 \times 10^{-4} \mathrm{M}\right)$ or $\operatorname{SNP}\left(10^{-9}-3 \times 10^{-5} \mathrm{M}\right)$, added at $30 \mathrm{~s}$ intervals.

Experiment design and data analysis. In all instances, the dependent variable was the relaxant response obtained as a percentage of the maximal contraction induced by $\mathrm{PE}\left(10^{-6} \mathrm{M}\right)$ or $\mathrm{KCl}(80 \mathrm{mM})$. Sigmoidal regression to lead $\mathrm{pEC}_{50}$ values (- $\log$ of the molar concentration of agonist to produce $50 \%$ of the maximal relaxation in contracted rings) were obtained from concentration-response curves. Each point represents the means \pm SEM of at least five experiments. Analysis of variance with Dunnett's post test were applied to compare three or more groups and Student $t$ test to compare two groups. $\mathrm{p}<0.05$ was considered significant. The GraphPad Sofware (version 4.0; San Diego, CA, USA) was used for data analysis.

Drugs and chemicals. The following salts and drugs were used: $\mathrm{NaCl}, \mathrm{CaCl}_{2}, \mathrm{NaHPO}_{4}, \mathrm{NaHCO}_{3}$, glucose (Panreac), $\mathrm{KCl}, \mathrm{MgCl}_{2}, \mathrm{KH}_{2} \mathrm{PO}_{4}$ and $\mathrm{MgSO}_{4}$ (Probus), ascorbic acid (Prolabo), phenylephrine hydrochloride, acetylcholine chloride, indomethacin, LNAME, L-arginine, D-arginine, ODQ, dipyridamole, glibenclamide, dimethylsulfoxide, verapamil hydrochloride, sodium nitroprusside, atropine sulfate, and propranolol hydrochloride (Sigma-Aldrich). Ayanin, glibenclamide and dipyridamole was dissolved in DMSO. All other substances were dissolved in physiological saline solution. The final DMSO concentrations in the bathing media were always less than $0.1 \%$. Control tests demonstrated that this amount of DMSO failed to exhibit any response. 
Table 1

Vasorelaxant effect of ayanin against $\mathrm{KCl}(80 \mathrm{mM})$ and phenylephrine $\left(\mathrm{PE}, 10^{-6} \mathrm{M}\right)$ alone and in the presence of different receptor antagonists in rat aorta rings

\begin{tabular}{|c|c|c|c|}
\hline Treatment & PE-contraction (mg) & $\mathrm{pEC}_{50}$ & Maximal response $\left(E_{\max }\right)$ \\
\hline $\mathrm{KCl}(80 \mathrm{mM})$ & $3335 \pm 197$ & ND & $35.47 \pm 3.65^{*}$ \\
\hline $\mathrm{PE}\left(10^{-6} \mathrm{M}\right)$ & $3439 \pm 165$ & $5.84 \pm 0.05$ & $92.99 \pm 1.30$ \\
\hline L-NAME $\left(10^{-4} \mathrm{M}\right)+\mathrm{PE}$ & $4882 \pm 189^{*}$ & ND & $32.99 \pm 7.14^{*}$ \\
\hline ODQ $\left(10^{-6} \mathrm{M}\right)+\mathrm{PE}$ & $5242 \pm 101^{*}$ & ND & $40.88 \pm 5.50^{*}$ \\
\hline L-ARG $\left(10^{-4} \mathrm{M}\right)+\mathrm{L}-\mathrm{NAME}\left(10^{-4} \mathrm{M}\right)+\mathrm{PE}$ & $3834 \pm 201$ & $5.61 \pm 0.04$ & $93.02 \pm 2.66$ \\
\hline D-ARG $\left(10^{-4} \mathrm{M}\right)+\mathrm{L}-\mathrm{NAME}\left(10^{-4} \mathrm{M}\right)+\mathrm{PE}$ & $4972 \pm 158^{*}$ & ND & $30.12 \pm 6.07^{*}$ \\
\hline Indomethacin $\left(5 \times 10^{-6} \mathrm{M}\right)+\mathrm{PE}$ & $3876 \pm 182^{*}$ & $5.43 \pm 0.04^{*}$ & $90.70 \pm 2.27$ \\
\hline Dipyridamole $\left(3 \times 10^{-7} \mathrm{M}\right)+\mathrm{PE}$ & $2300 \pm 205^{*}$ & $6.05 \pm 0.16$ & $92.29 \pm 2.49$ \\
\hline Verapamil $\left(10^{-7} \mathrm{M}\right)+\mathrm{PE}$ & $1694 \pm 108^{*}$ & $5.99 \pm 0.11$ & $95.10 \pm 1.54$ \\
\hline Glibenclamide $\left(10^{-6} \mathrm{M}\right)+\mathrm{PE}$ & $2818 \pm 159$ & $5.90 \pm 0.01$ & $96.61 \pm 3.61$ \\
\hline Propranolol $\left(10^{-6} \mathrm{M}\right)+\mathrm{PE}$ & $3587 \pm 186$ & $5.92 \pm 0.09$ & $87.97 \pm 3.21$ \\
\hline Atropine $\left(3 \times 10^{-5} \mathrm{M}\right)+\mathrm{PE}$ & $2945 \pm 205$ & $5.82 \pm 0.07$ & $90.98 \pm 4.02$ \\
\hline
\end{tabular}

Data are the mean \pm SEM. $n \geq 5$ experiments. $p \mathrm{pC}_{50}$ represents -log molar concentration of ayanin to produce $50 \%$ of the maximal relaxation. $E_{\max }$, maximal relaxation (\%). ${ }^{*} p<0.05$ compared with $P E\left(10^{-6} \mathrm{M}\right)$. ND, not determined.

\section{RESULTS}

The maximal contractile response obtained with $\mathrm{KCl}$ and $\mathrm{PE}$ in intact aorta rings was $3335 \pm 197 \mathrm{mg}(\mathrm{n}=26)$ and $3439 \pm 165(\mathrm{n}=52)$, respectively. In de-endothelized rings PE elicited a contraction of $3126 \pm 161 \quad(n=33)$ (Table 1). Ayanin induced a greater relaxant effect against $\mathrm{PE}\left(\mathrm{pEC}_{50}=5.84 \pm 0.05\right)$ than $\mathrm{KCl}$ (Table 1, Figure 2).

Pretreatment of the endothelium-intact rings with LNAME (Figure 3) or ODQ (Figure 4) significantly reduced ayanin-induced relaxation. The effects of $\mathrm{L}$ NAME was completely reversed by L-arginine $\left(\mathrm{pEC}_{50}=5.61 \pm 0.04\right)$, but not by $\mathrm{D}$-arginine (Table 1 , Figure 3).

The relaxant response to ayanin was not affected by pretreatment with dipyridamole, atropine, verapamil or propranolol (Table 1), and slightly by indomethacin (Figure 4). Finally, ayanin unchanged the ACh relaxing effect (pEC50=7.55 \pm 0.04$)$ and slightly modified SNP relaxation (pEC50=7, Table 2, Figure 5).

\section{DISCUSSION}

The results of ayanin in $\mathrm{KCl}$ - and $\mathrm{PE}$-intact rings and in PE de-endothelized rings show that this flavonoid

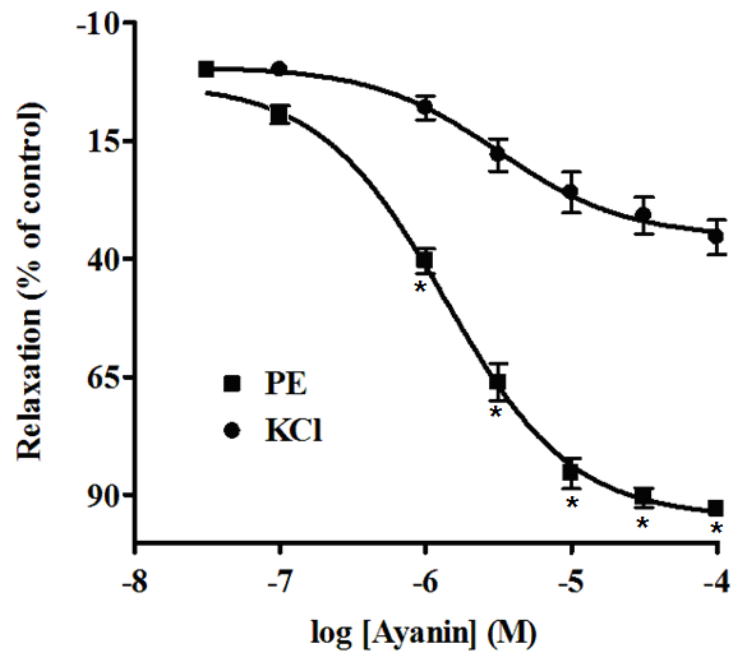

Figure 2. Concentration-response induced by ayanin in endothelium-intact rat aorta rings contracted with phenylephrine (PE, $\left.10^{-6} \mathrm{M}\right)$ or $\mathrm{KCl}(80 \mathrm{mM})$, ${ }^{*} \mathrm{p}<0.05$ (Student t test).

exerts anti-adrenergic effect of endothelium-dependent origin. Subsequent experiments with the NO synthase inhibitor L-NAME and ODQ, a guanilyl cyclase inhibitor, which were able to reduce markedly ayanin vasodilatation, support a NO/cGMPc dependent mechanism. 
Table 2

Effect of ayanin $\left(10^{-6} \mathrm{M}\right)$ on the relaxant responses of acetylcholine $\left(\mathrm{ACh}, 10^{-8}-3 \times 10^{-4} \mathrm{M}\right)$ and sodium nitroprusside (SNP, $10^{-9}-3 \times 10^{-5} \mathrm{M}$ ) in endothelium-intact aorta rings precontracted with phenylephrine (PE, $\left.10^{-6} \mathrm{M}\right)$

\begin{tabular}{|c|c|c|c|}
\hline Treatment & PE-contraction (mg) & $\mathrm{pEC}_{50}$ & Maximal response $\left(E_{\max }\right)$ \\
\hline $\operatorname{ACh}\left(10^{-8}-3 \times 10^{-4} \mathrm{M}\right)$ & $3439 \pm 165$ & $7.82 \pm 0.02$ & $64.41 \pm 3.25$ \\
\hline Ayanin $\left(10^{-6} \mathrm{M}\right)+\operatorname{ACh}\left(10^{-8}-3 \times 10^{-4} \mathrm{M}\right)$ & $3192 \pm 202$ & $7.55 \pm 0.04$ & $71.73 \pm 3.15$ \\
\hline $\operatorname{SNP}\left(10^{-9}-3 \times 10^{-5} \mathrm{M}\right)$ & $3439 \pm 165$ & $8.38 \pm 0.006$ & $100.00 \pm 0.00$ \\
\hline Ayanin $\left(10^{-6} \mathrm{M}\right)+\operatorname{SNP}\left(10^{-9}-3 \times 10^{-5} \mathrm{M}\right)$ & $3192 \pm 202$ & $8.08 \pm 0.01^{*}$ & $99.92 \pm 0.08$ \\
\hline
\end{tabular}

Data are the mean \pm SEM of $>5$ experiments. $\mathrm{pEC}_{50}$ represents -log molar concentration of Ach or SNP to produce $50 \%$ of the maximal relaxation. $E_{\max }$, maximal relaxation (\%). ${ }^{*} p<0.05$ compared with $P E\left(10^{6} \mathrm{M}\right)(\mathrm{E}+)$. ND, not determined.

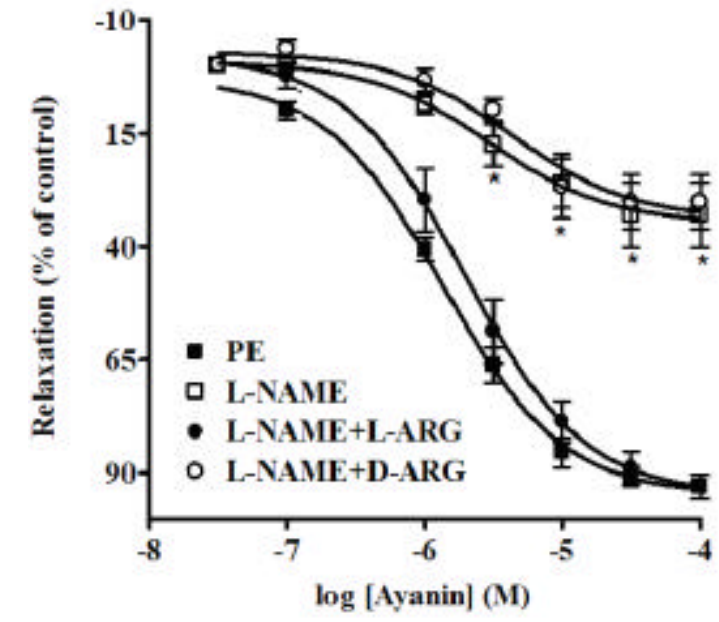

Figure 3. Concentration response induced by ayanin in endothelium-intact rat aorta rings contracted with phenylephrine (PE, $10^{-6} \mathrm{M}$ ), in absence and presence of: L-NAME $\left(10^{-4} \mathrm{M}\right)$, L-NAME plus L-arginine $\left(10^{-4} \mathrm{M}\right)$ and $\mathrm{L}-\mathrm{NAME}$ plus $\mathrm{D}$-arginine $\left(10^{-4} \mathrm{M}\right),{ }^{*} \mathrm{p}<0.05$ (Anova and Dunnett tests).

It is noticeable that L-arginine (the substrate for NO synthesis), but not D-arginine, was able to reverse the inhibitory effects induced by L-NAME against ayanin. These findings suggest that ayanin enhances the production of NO from L-arginine in the vascular endothelium. It is known that nitric oxide (the endothelium derived relaxing factor, EDRF ${ }^{20}$ activates soluble guanylyl cyclase, causing the formation of cyclic GMP and subsequently vascular relaxation ${ }^{21}$. Since ODQ interferes directly with soluble guanylyl cyclase activated

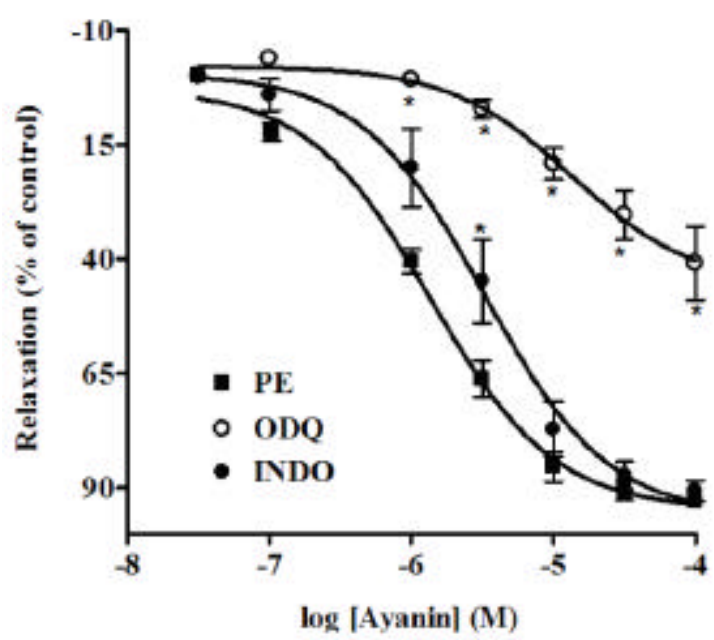

Figure 4. Concentration response induced by ayanin in endothelium-intact rat aorta rings contracted with phenylephrine (PE, $10^{-6} \mathrm{M}$ ) in absence and presence of $O D Q\left(10^{-6} \mathrm{M}\right)$ or indomethacin $\left(5 \times 10^{-6} \mathrm{M}\right)$, ${ }^{*} p<0.05$ (Anova and Dunnett tests).

by $\mathrm{NO}^{22}$, relaxation induced by ayanin may be related to the production of NO, resulting in an increase of the cGMP in the endothelium.

The cellular accumulation of cGMP depends upon the rate of their synthesis and their breakdown. The latter is achieved by cyclic nucleotide phosphodiesterase (PDE) isoforms PDE1 and/or PDE5 ${ }^{23}$ isolated in vascular smooth muscle cells. The potentiating of vasodilator effects of agents that increase cGMP has become a simple test to study the possible role of PDE 


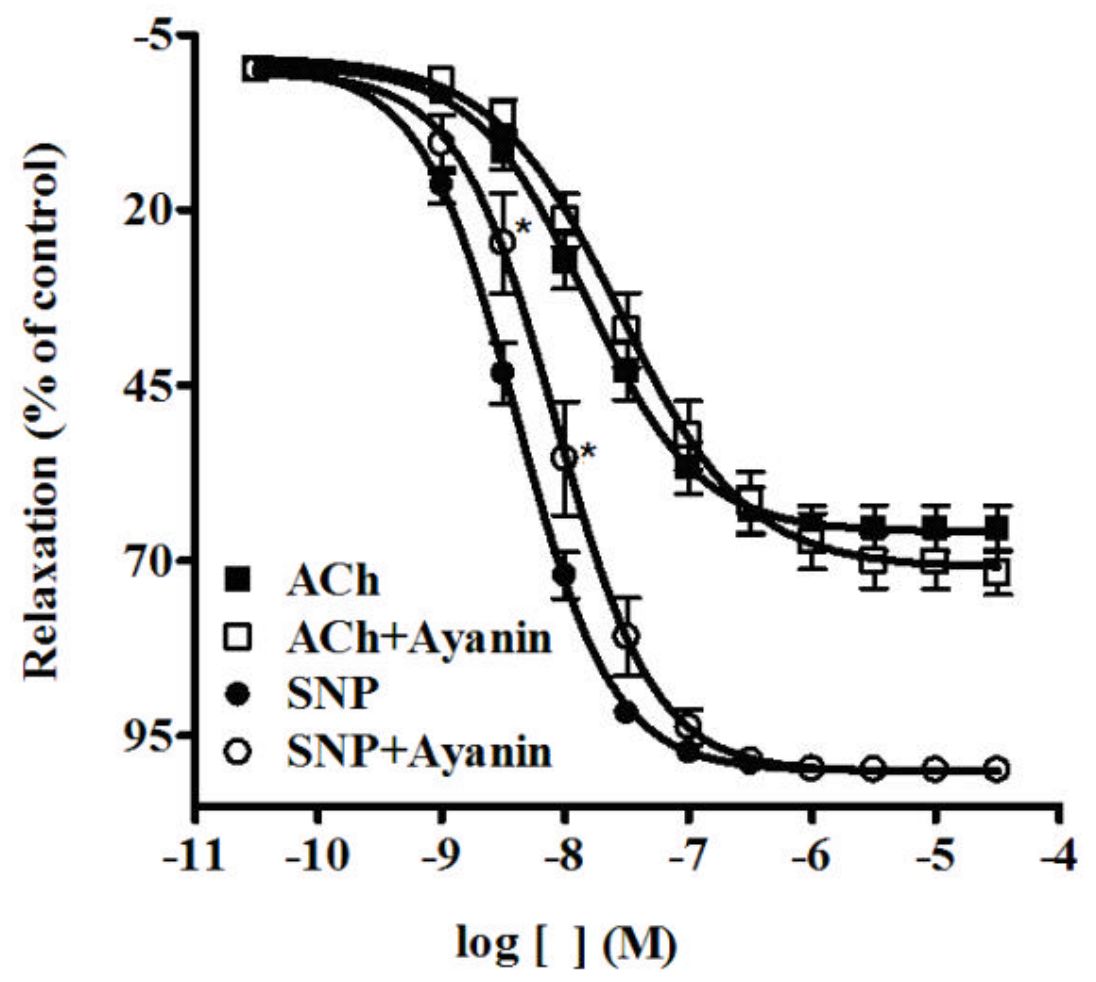

Figure 5. Concentration response induced by acetylcholine ( $\mathrm{ACh}, 10^{-8}-3 \times 10^{-4} \mathrm{M}$ ) and sodium nitroprusside (SNP, $10^{-9}-3 \times 10^{-5} \mathrm{M}$ ) in endothelium-intact rat aorta rings contracted with phenylephrine $\left(\mathrm{PE}, 10^{-6} \mathrm{M}\right)$ in absence and presence of ayanin $\left(10^{-6} \mathrm{M}\right),{ }^{*} \mathrm{p}<0.05$ (Student $\mathrm{t}$ test)

inhibition in the relaxant effect of vasodilators. In these experiments, ayanin slightly increased the relaxant effect of SNP, a NO donor. Furthermore, dipyridamole, a cGMP-PDE5 inhibitor did not modify the relaxant responses to ayanin. Hence, these results suggest that inhibition of the GMP-dependent PDE is not mainly linked to the vasodilator effect of ayanin.

Blockage of cyclo-oxygenase by indomethacin $\left(5 \times 10^{-6} \mathrm{M}\right)$ produced a rightward shift in the concentrationresponse curve for ayanin. The $\mathrm{pEC}_{50}$ value of ayanin in the presence of the indomethacin was significantly decreased from $5.84 \pm 0.05$ to $5.43 \pm 0.04$ ( $p<0.05$, Figure 4 , Table 1). Therefore, it is possible in some degree that endothelial vasorelaxant factors derived from cyclooxigenase participated in the relaxant effect of ayanin.

Also, according to experiments with: atropine, a muscarinic receptor antagonist; verapamil, aL-typecalcium channel blocking agent; propranolol, a ?-adrenoceptor blocking agent; and glibenclamide, a $\mathrm{K}^{+}{ }_{\mathrm{ATP}}$ channel blocker (Table 1), it can be presumed that muscarinic agonism, beta agonism, voltage-dependentcalcium channel activation, and $\mathrm{K}_{\text {ATP }}^{+}$channel activation do not seem important action mechanisms related to the ayanin relaxant profile. However, these observations do not rule out the possibility that other types of pharmaco-dynamic interactions may mediate ayanin-induced relaxation.

In conclusion, the ayanin flavonoid induces endothelium-dependent relaxation in Wistar rat aorta mainly related to NO/cGMP pathway. Further work is necessary to clarify the mechanisms involved in this effect. Since ayanin is the predominant compound isolated from C. schiedeanus («almizclillo»), it is highly probable that it plays an important role in the cardiovascular effects described for this specie. These results support the traditional use of $C$. schiedeanus for the treatment of arterial hypertension. 
Conflict of interest. None of the authors has conflicts of interest related to this study.

\section{ACKNOWLEDGMENTS}

This work was supported by the project: ALFARELAPLAMED.2, Subprograma X, Química Fina Farmacéutica of CYTED and the office of the Vice rector of Research, Universidad Nacional de Colombia (Project 9356).

\section{REFERENCES}

1. Renaud S, Lorgeril M. Wine, alcohol, platelets and the French paradox for coronary heart disease. Lancet. 1992;339: 15236.

2. Hertog MGL, Feskins EJM, Hollman PCH, Katan MB, Kromhout D. Dietary antioxidant flavonoids and risk of coronary heart disease: the Zutphen Elderley study.Lancet. 1993; 342: 1007-11.

3. Hertog MGL, Sweetnam PM, Elwood AM, Fehily PC, KromhoutD. Antioxidant flavonols and ischemic heart disease in a Welsh population of men: the Caerphilly study. Am JClin Nutr. 1997; 65: 1489-94.

4. Fuhrman B, Lavy A, Aviram M. Consumption of red wine meals reduces the susceptibility of human plasma and LDL to lipid peroxidation. Am J Clin Nutr. 1995;61:549-54.

5. Duarte J, Pérez-Vizcaíno F, Utrilla P, Jiménez J, Tamargo J, Zarzuelo A. Vasodilatory effects of flavonoids in rat aorta smooth muscle. Structure-activity relationships. Gen Pharmacol. 1993; 24: 857-62.

6. Duarte J, Pérez-Vizcaíno F, Zarzuelo A, Jiménez J, Tamargo J. Vasodilator effects of quercetin on isolated rat vascular smooth muscle. Eur J Pharmcol. 1993;239: 1-7.

7. Duarte J, Pérez-Vizcaíno F, Zarzuelo A, Jiménez J, Tamargo J. Inhibitory effects of quercetin and staurosporine on phasic contractions in rat vascular smooth muscle. Eur J Pharmcol. 1994.2: 149-56.

8. Fitzpatrick DF, Hirschfield SL, Ricci T, Jantzen P, Coffey RG. Endothelium-dependent vasorelaxation caused by various plant extracts. J Cardiovasc Pharmacol. 1995; 26: 90-5.

9. Herrera MD, Zarzuelo A, Jiménez J, Marhuenda E, Duarte J. Effects of flavonoids on rat aorta smooth muscle contractility: structure-activity relationship. Gen Pharmacol. 1996;27: 273-7.

10. Pérez-VizcaínoF, Ibarra M, Cogolludo AL, Duarte J,ZaragozáArnáez F, Moreno L, et al. Endothelium-independent vasodilator effects of the flavonoid quercetin and its methylated metabolites in rat conductance and resistance aretries. $J$ Pharmacol Exp Ther. 2002; 302:66-72.

11. Chen Z, Su Y, Lau C, Law W, Huang Y. Endotheliumdependent contraction and direct relaxation induced by baicalein in rat mesenteric artery. Eur J Pharmacol. 1999; 374:41-7.

12. Chan E, Pannangpetch P, Woodman O. Relaxation to flavones and flavonols in rat isolated thoracic aorta: mechanism of action and structure-activity relationships.J Cardiovasc Pharmacol. 2000; 35: 326-33

13. Ajay M, Gilani AH, Mustafa MR. Effects of flavonoids on vascular smooth muscle of the isolated rat thoracic aorta. Life Sci. 2003; 74:603-12.

14. Guerrero MF, Carrón R, Martín ML, San Román L, Reguero MT. Antihypertensive and vasorelaxant effects of aqueous extract from Croton schiedeanus Schlecht in rats. J Ethnopharmacol. 2001; 75: 33-6.

15. Guerrero MF, Puebla P, Carrón R, Martín ML, San Román L. Quercetin 3,7-dimethyl ether: a vasorelaxant flavonoid isolated from Croton schiedeanus Schlecht.J Pharm Pharmacol.2002; 54: $1373-8$.

16. Ko WC, Kuo SW, Sheu JR, Lin CH, Tzeng H, Chen CM. Relaxant effects of quercetin methyl ether derivatives in isolated guinea pig trachea and their structure-activity relationships. Planta Med. 1999; 65:273-5.

17. Malan E, Roux DG. Flavonoids from Distemonanathus benthamianus Baillon. Methoxylated Flavones and Interrelationships of Benthamianin, [2]Benzopyrano[4,3b][1]benzopyran. J Chem Soc Perkins Trans. 1979; 1: 2696703 .

18. Agraval PK. Carbon-13 NMR of flavonoids. Amsterdam Elsevier; 1989.

19. Furchgott RF,Zawadzki JV. The obligatory role of endothelial cells in the relaxation of arterial smooth muscle by acetylcholine. Nature. 1980;288:373-6.

20. Moncada S, Plamer RMJ, Higos EA. Biosynthesis of nitric oxide from L-arginine: A pathway for the regulation of cell function and communication. Biochem Pharmacol. 1989;38: 1709-15.

21. IgnarroLJ, KadowitzPJ. The pharmacological and physiological role of cyclic GMP in vascular smooth muscle relaxation.Ann Rev Pharmacol Toxicol. 1985; 25: 171-91.

22. Garthwaite J, Southam E, Boulton CL, Nielsen EB, Schmidt K, Mayer B. Potent and selective inhibition of nitric oxidesensitive guanylyl cyclase by $1 \mathrm{H}-[1,2,4]$ oxadiazolo[4,3a]quinoxalin-1-one. MolPharmacol. 1995; 48: 184-8.

23. Komas N, Lugnier C, Stoclet JC. Endothelium-dependent and independent relaxation of the rat aorta by cyclic nucleotide phosphodiesterase inhibitors. Br J Pharmacol. 1991; 104: 495-503. 